\title{
Metabolism of ferulic acid via vanillin using a novel CoA-dependent pathway in a newly- isolated strain of Pseudomonas fluorescens
}

\author{
Arjan Narbad and Michael J. Gasson
}

Department of Genetics and Microbiology, Institute of Food Research, Norwich Research Park, Colney, Norwich NR4 7UA, UK
Author for correspondence: Arjan Narbad. Tel: +44 1603 255252. Fax: +441603 458414. e-mail: Arjan.Narbad@BBSRC.AC.UK

\begin{abstract}
A soil bacterium, designated Pseudomonas fluorescens AN103, was isolated based on its ability to grow on ferulic acid as a sole source of carbon and energy. In addition, this strain was found to metabolize a number of related phenolic substrates which contained a hydroxyl group at the para position of the aromatic ring. During growth on ferulic acid, transient accumulation of vanillic acid and trace amounts of protocatechuic acid were detected in the culture medium. Washed cells grown on ferulic acid readily oxidized vanillin, vanillic acid and protocatechuic acid, the three putative intermediates of the metabolic pathway. The side-chain cleavage of ferulic acid to produce vanillin was demonstrated in vitro for the first time and this enzyme-catalysed reaction was shown to have an essential requirement for COASH, ATP and $\mathrm{MgCl}_{2^{*}}$ This conversion involved a two-step process involving a COA ligase followed by the side-chain cleavage. The addition of NAD increased the oxidation of vanillin to vanillic acid and had an overall effect of increasing the rate of ferulic acid cleavage. The application of ${ }^{13} \mathrm{C}$-NMR studies in vitro revealed acetyl-COA as the $C_{2}$ side-chain cleavage product. High levels of inducible ferulate-COA ligase and NAD-linked vanillin dehydrogenase were detected and a novel pathway for ferulic acid metabolism in this organism is proposed.
\end{abstract}

Keywords : ferulic acid, vanillin, vanillic acid, ferulate-CoA ligase, vanillin dehydrogenase

\section{INTRODUCTION}

Biodegradation and biotransformation of phenylpropanoids such as ferulic acid has received attention for two main reasons. Ferulic acid is a major component of lignin in plants (Ishikawa et al., 1963; Provan et al., 1994) and it has been used as a simple lignin model substrate (Ander \& Eriksson, 1978). Numerous bacteria and fungi capable of degrading ferulic acid have been isolated and studied in order to unravel the complex process of lignin biodegradation (Cartwright \& Smith, 1967; Henderson, 1961; Ishikawa et al., 1963). Ferulic acid is also found in significant quantities in the cell walls of many agriculturally important crops such as wheat, maize and sugar beet (Provan et al., 1994). It therefore represents a readily available natural raw material from which to generate value-added products such as vanillin (Hagedorn \& Kaphammer, 1994).

In a number of micro-organisms, the initial steps in degradation of ferulic acid involve a $\mathrm{C}_{1}$-cleavage of the side chain, resulting in the formation of 4-hydroxy-3methoxystyrene (Edlin et al., 1995; Huang et al., 1993; Nazareth \& Mavinkurve, 1986; Rahouti et al., 1989; Rosazza et al., 1995). The decarboxylase enzyme involved in this step has been well characterized both in bacteria (Huang et al., 1994) and in Saccharomyces cerevisiae (Clausen et al., 1994). In other microbial systems, the initial step is the $\mathrm{C}_{2}$-cleavage of the ferulic acid side chain with production of the more valuable flavour compounds vanillin or vanillic acid. In most studies to date, the $\mathrm{C}_{2}$ cleavage is inferred from respirometric studies, as reported in Pseudomonas cepacia (Andreoni et al., 1984) and Escherichia coli (Otük, 1985), or from detection of the intermediates in the cell culture media. Examples of the latter include the reports on Corynebacterium glutamicum (Labuda et al., 1993), Pseudomonas strains (Cartwright \& Buswell, 1967; Omori et al., 1988) and Streptomyces setonii (Sutherland et al., 1983), in which the presence of low 
levels of either vanillin, vanillic acid or both was observed in the culture media supplemented with ferulic acid. However, biochemical information on the $\mathrm{C}_{2}$ cleavage of the side chain is very limited. Toms $\&$ Wood (1970) reported an oxidative-type cleavage in $P$. acidovorans with acetic acid as the side-chain cleavage product. Gurujeyalakshmi \& Mahadevan (1987) proposed a deacetylation as the first step in ferulic acid dissimilation by Bacillus subtilis. Sutherland et al. (1983) also demonstrated the formation of acetic acid from ferulic acid in cell-free extracts of Streptomyces setonii.

In this paper we report the isolation and characterization of a strain of Pseudomonas capable of growth on ferulic acid. Evidence is presented which demonstrates that this bacterium metabolizes ferulic acid via vanillin. A novel metabolic route is proposed in which CoASH and ATP are required for initial $\mathrm{C}_{2}$ cleavage of the side chain.

\section{METHODS}

Chemicals. All chemicals were purchased from Sigma or from $\mathrm{BDH}$ and were of the highest grade available.

Synthesis of $\left[2-{ }^{13} \mathrm{C}\right]$ ferulic acid. The ${ }^{13} \mathrm{C}$-labelled ferulic acid was synthesized from vanillin and $\left[2-{ }^{13} \mathrm{C}\right]$ malonic acid (MSD Isotopes) by the method described by Pearl \& Beyer (1951).

Isolation of Pseudomonas fluorescens AN103. The soil enrichment technique of Henderson (1961) was used for bacterial isolation. A sample from a soil site rich in moss peat was aseptically collected from approximately $10 \mathrm{~cm}$ below the soil surface. Soil $(1 \mathrm{~g})$ was thoroughly mixed with $50 \mathrm{ml}$ sterile water using an Ultraturrax homogenizer, and $1 \mathrm{ml}$ of this soil suspension was used to inoculate $50 \mathrm{ml}$ minimal medium (see below) containing $10 \mathrm{mM}$ ferulic acid as the carbon source. The flasks were incubated for $6 \mathrm{~d}$ at $25^{\circ} \mathrm{C}$. Samples of $1 \mathrm{ml}$ from each flask were used to inoculate fresh medium $(50 \mathrm{ml})$, followed by further incubation for $6 \mathrm{~d}$. The cultures were diluted in T2 buffer ( $\mathrm{pH} 7$ ) and $0.1 \mathrm{ml}$ aliquots of $10^{-2}-10^{-4}$ dilutions were plated onto ferulic acid minimal agar and incubated for $7 \mathrm{~d}$. The composition of $\mathrm{T} 2$ buffer was $\left(\mathrm{g} \mathrm{l}^{-1}\right)$ : $\mathrm{NaCl}, 4 ; \mathrm{K}_{2} \mathrm{SO}_{4}, 5 ; \mathrm{KH}_{2} \mathrm{PO}_{4}, 1 \cdot 5 ; \mathrm{Na}_{2} \mathrm{HPO}_{4}, 3 ; \mathrm{MgSO}_{4}, 0 \cdot 12$; $\mathrm{CaCl}_{2}, 0 \cdot 11$. Single colonies were replica plated onto agar plates with vanillin as the carbon source. A single colony of the bacterium designated AN103 was selected for further experiments and was stored on LB agar slopes at $4{ }^{\circ} \mathrm{C}$.

Media and culture conditions. Standard minimal media were prepared by the addition of a single carbon and energy source to a basal inorganic salts solution containing a trace-element solution $(0.01 \%, \mathrm{v} / \mathrm{v})$ and $\left(\mathrm{g} \mathrm{l}^{-1}\right): \mathrm{KH}_{2} \mathrm{PO}_{4}, 5 ;\left(\mathrm{NH}_{4}\right)_{2} \mathrm{SO}_{4}, 1$; $\mathrm{MgSO}_{4} .7 \mathrm{H}_{2} \mathrm{O}, 0.05 ; \mathrm{FeSO}_{4} \cdot 7 \mathrm{H}_{2} \mathrm{O}, 0.005$. The composition of the trace-element solution was (\% $\mathrm{w} / \mathrm{v})$ : EDTA, $5 ; \mathrm{ZnSO}_{4} .7 \mathrm{H}_{2} \mathrm{O}, 2.2 ; \mathrm{CaCl}_{2}, 0.55 ; \mathrm{MnCl}_{2} .5 \mathrm{H}_{2} \mathrm{O}$, $0.50 ; \quad\left(\mathrm{NH}_{4}\right)_{6} \mathrm{Mo}_{7} \mathrm{O}_{24} .4 \mathrm{H}_{2} \mathrm{O}, 0.11 ; \mathrm{CuSO}_{4} .5 \mathrm{H}_{2} \mathrm{O}, 0.16$; $\mathrm{CoCl}_{2} .6 \mathrm{H}_{2} \mathrm{O}, 0 \cdot 16$. The $\mathrm{pH}$ of the media was adjusted to $7 \cdot 0$. $\mathrm{MgSO}_{4}, \mathrm{FeSO}_{4}$ and trace-element solutions were autoclaved separately. All the carbon substrates were filter sterilized and used at a concentration of $10 \mathrm{mM}$ unless stated otherwise. Solid media were prepared by the addition of $1.5 \%$ agar. $P$. fluorescens AN103 was grown at $25^{\circ} \mathrm{C}$. Liquid cultures were incubated in an orbital shaker at 120 r.p.m.

Electron microscopy. A single drop of bacterial culture was dried onto a carbon-coated grid and the bacteria were negatively stained with uranyl acetate. The samples were examined in a JEOL 1200 transmission electron microscope.
HPLC analysis. Reverse-phase HPLC analysis was performed with an LKB Pharmacia liquid chromatographic system model 2150 linked to a Kratos Spectraflow 773 detector set at $260 \mathrm{~nm}$ and an SP4270 integrator (Spectra-Physics). Test samples $(10-20 \mu \mathrm{l})$ were injected in a $\mu$ Bondapack C18 column of $30 \mathrm{~mm}$ length (Millipore) or $15 \mathrm{~mm}$ length (Capital HPLC). An isocratic linear solvent system of $20 \%(\mathrm{v} / \mathrm{v})$ methanol in $1 \mathrm{mM}$ trifluoroacetic acid was used with a flow rate of 1-2 $\mathrm{ml} \mathrm{min} \mathrm{m}^{-1}$. The phenolics were quantified by measurement of the peak area and the concentration values extrapolated from the corresponding standard curve prepared for each compound.

NMR spectroscopy. ${ }^{13} \mathrm{C}-\mathrm{NMR}$ spectra were recorded at $90.55 \mathrm{MHz}$ on a Bruker AMX360 spectrometer operating in the Fourier transform mode (Narbad et al., 1989). All the samples contained $20 \% \mathrm{D}_{2} \mathrm{O}$ to provide the field-frequency lock. The acquisition parameters were as follows: spectral width, $22 \mathrm{kHz}$; pulse width, $2 \mu \mathrm{s}\left(30^{\circ}\right)$; data points, $33 \mathrm{~K}$; repetition delay, $1 \mathrm{~s}$; number of scans, 3000 . Proton decoupling (Waltz-16) was applied throughout.

Samples for NMR analysis were prepared in a total volume of $0.6 \mathrm{ml}$ and contained $260 \mathrm{mM}$ potassium phosphate buffer $\mathrm{pH} 7 \cdot 0,5 \mathrm{mM}\left[2-{ }^{13} \mathrm{C}\right]$ ferulic acid, $3 \mathrm{mM}$ ATP, $3 \mathrm{mM} \mathrm{MgCl}{ }_{2}$, $1.3 \mathrm{mM}$ NAD, $0.25 \mathrm{mM}$ CoASH and cell-free extract $(100 \mu \mathrm{g}$ protein). The mixture was filter sterilized through a $0.22 \mu \mathrm{m}$ membrane and then incubated at $25^{\circ} \mathrm{C}$ for $8 \mathrm{~h}$. The cell-free extracts were omitted in the control tubes. Samples were transferred to $5 \mathrm{~mm}$ NMR tubes for analysis at $20^{\circ} \mathrm{C}$.

Manometry. Oxygen uptake by whole cells was determined using a Warburg apparatus operating at $25^{\circ} \mathrm{C}$. The main compartment of the flasks contained $50 \mathrm{mM}$ potassium phosphate buffer, $\mathrm{pH} 7 \cdot 2$, and the test substrate in a total volume of $2 \mathrm{ml}$. The side arm contained $1 \mathrm{ml}$ washed cells (equivalent to $4 \mathrm{mg}$ dry weight) previously grown in ferulic acid. The centre well contained $0.1 \mathrm{ml} 10 \%(\mathrm{w} / \mathrm{v}) \mathrm{KOH}$ and a filter paper wick to absorb any released $\mathrm{CO}_{2}$. The reaction was started by tipping the contents of the side arm into the main compartment. Readings were taken at $10 \mathrm{~min}$ intervals.

Analysis of metabolites in culture media. Samples of the culture supernatant $(10-20 \mu \mathrm{l})$ were injected into the HPLC system. For detection of trace amounts of metabolites, ethyl acetate extraction was performed on $200 \mathrm{ml}$ culture supernatant from a $P$. fluorescens AN103 culture collected during the mid-exponential phase of growth. Phenolic metabolites were partitioned into an equal volume of ethyl acetate. After rotary evaporation of the solvent, the phenolics were recovered in $2 \mathrm{ml} 80 \%(\mathrm{v} / \mathrm{v})$ methanol and then used for HPLC analysis.

Preparation of cell extracts. Cells grown on different carbon substrates were harvested during the late-exponential phase of growth by centrifugation at $10000 \mathrm{~g}$ for $20 \mathrm{~min}$. The cell pellet was washed twice in $20 \mathrm{mM}$ cold potassium phosphate buffer, $\mathrm{pH} 7 \cdot 0$, and then stored at $-20^{\circ} \mathrm{C}$. All subsequent procedures were carried out at $4{ }^{\circ} \mathrm{C}$. Prior to preparation of cell extracts, the cells were thawed and resuspended in $50 \mathrm{mM}$ cold potassium phosphate buffer containing $10 \mathrm{mM}$ DTT. The cell suspension (10-20 ml) was sonicated using an MSE Soniprep equipped with a titanium probe (tip diameter $9.5 \mathrm{~mm}$ ) and operating at $20 \mu \mathrm{m}$ amplitude. To prevent heating, the vessel containing the cell suspension was surrounded by ice and sea salt. Sonication was applied in short bursts of $20 \mathrm{~s}$ with a total exposure time of $1.7 \mathrm{~min}$.

Protein assay. The total protein concentration was determined by the method of Bradford (1976) using reagents supplied by Bio-Rad. 
Measurement of ferulic acid side-chain cleavage activity in vitro. The ability of cell-free extracts of ferulic-acid-grown cells to convert ferulic acid was examined at $25^{\circ} \mathrm{C}$. The complete reaction mixture $(1.5 \mathrm{ml})$ contained $260 \mathrm{mM}$ potassium phosphate buffer $\mathrm{pH} 7 \cdot 0,1 \mathrm{mM}$ ferulic acid, $3 \mathrm{mM}$ ATP, $3 \mathrm{mM} \mathrm{MgCl}, 1.3 \mathrm{mM}$ NAD, $0.25 \mathrm{mM}$ CoASH and cellfree extract $(200 \mu \mathrm{g}$ protein). The mixture was filter sterilized through a $0.22 \mu \mathrm{m}$ membrane to remove any remaining whole cells and incubated for $4 \mathrm{~h}$. Ten microlitre samples were used for analysis by HPLC.

In vitro conversion of vanillin to vanillic acid. Analyses were carried out exactly as above except that ferulic acid was replaced by $1 \mathrm{mM}$ vanillin, and $\mathrm{ATP}, \mathrm{MgCl}_{2}$ and $\mathrm{CoASH}$ were omitted. The reverse reaction was also measured by replacing vanillin with vanillic acid.

Enzyme assays. Ferulate-CoA ligase was assayed spectrophotometrically at $30^{\circ} \mathrm{C}$; the method was based on that described by Rhodes \& Wooltorton (1973). The reaction mixture ( $1 \mathrm{ml}$ ) contained $100 \mathrm{mM}$ Tris $/ \mathrm{HCl}$ pH 7.5, $2.5 \mathrm{mM}$ $\mathrm{MgCl}_{2}, 2.5 \mathrm{mM}$ ATP, $0.5 \mathrm{mM}$ ferulic acid, $0.2 \mathrm{mM} \mathrm{CoASH}$ and $100 \mu \mathrm{g}$ cell-free extract. The assay was started by addition of the CoASH and the formation of feruloyl-CoA was measured at $346 \mathrm{~nm}$ in a Uvicon 860 spectrophotometer (Kontron). The molar absorption coefficient value used for feruloyl-CoA was $1.9 \times 10^{4} \mathrm{M}^{-1} \mathrm{~cm}^{-1}$ as established by Zenk et al. (1980).

Vanillin dehydrogenase was assayed at $30^{\circ} \mathrm{C}$ by measuring the decrease in absorbance at $343 \mathrm{~nm}$ in the presence of NAD. The bacterial extract contained a high level of NADH oxidase which regenerated NAD. The molar extinction coefficient for vanillin was calculated to be $7 \cdot 2 \times 10^{3} \mathrm{M}^{-1} \mathrm{~cm}^{-1}$. The reaction mixture ( $1 \mathrm{ml}$ ) contained $100 \mathrm{mM}$ potassium phosphate buffer (pH 7.0), $5 \mathrm{mM}$ vanillin, $10 \mathrm{mM}$ NAD and cell-free extract (approximately $100 \mu \mathrm{g}$ protein).

\section{RESULTS}

\section{Bacterial identification}

Using an enrichment culture technique, at least 10 morphologically different bacteria were isolated based on their ability to grow on ferulic acid and vanillin as the sole source of carbon and energy. One such isolate, designated AN103, was selected for further studies. This strain appeared as a motile, strictly aerobic, nonpigmented Gram-negative rod with polar flagella. The bacterial dimensions were $0.8-1.2 \mu \mathrm{m}$ by $1.7-3.5 \mu \mathrm{m}$. The bacterium did not grow at $37^{\circ} \mathrm{C}$ or $41^{\circ} \mathrm{C}$ and the growth was more efficient at $25^{\circ} \mathrm{C}$ than at $30^{\circ} \mathrm{C}$. This strain exhibited positive responses in catalase oxidase, nitrate reduction, arginine dihydrolase, cytochrome oxidase, growth in $5 \% \mathrm{NaCl}$, levan and gelatin hydrolysis tests. The indole production, acid production from glucose or maltose, aesculin and gelatin hydrolysis, $\beta$-galactosidase, DNase, lecithinase, lipase, starch hydrolysis, urease, growth with 3-ketolactose, calcium glycerophosphate, acetamide alkalinization and ferric ammonium citrate tests were all negative. Assimilation tests were positive for glucose, mannose, $\mathrm{N}$-acetylglucosamine, gluconate, caprate, malate, citrate and phenylacetate, but negative for arabinose, mannitol, maltose, adipate, inositol and trehalose. The detailed identification of AN103 was based on the analysis of classical morphological and biochemical properties
Table 1. Relative growth of $P$. fluorescens AN103 on different carbon substrates

All carbon substrates were used at $10 \mathrm{mM}$ except vanillin $(2 \mathrm{mM})$. Fresh minimal medium $(50 \mathrm{ml})$ was inoculated with a sufficient volume of inoculum grown overnight in the same carbon source to give an initial $\mathrm{OD}_{600}$ of 0.05 . Eugenol, cinnamic acid, sinapinic acid, protocatechuic aldehyde and methanol ( $5 \mathrm{mM})$ did not support growth. The values shown are the $\mathrm{OD}_{600}$ values measured after $16 \mathrm{~h}$ incubation at $25^{\circ} \mathrm{C}$ and are the mean of two separate cultures.

\begin{tabular}{|ll|}
\hline Carbon source & Growth \\
\hline Ferulic acid & 0.89 \\
Caffeic acid & 0.70 \\
Vanillin & 0.18 \\
Vanillic acid & 1.10 \\
Protocatechuic acid & 0.68 \\
Glucose & 1.96 \\
Acetate & 0.42 \\
\hline & \\
\hline
\end{tabular}

Fig. 1. Growth of $P$. fluorescens AN103 on ferulic acid. Overnight culture $(10 \mathrm{ml})$ was used to inoculate $200 \mathrm{ml}$ ferulic acid $(10 \mathrm{mM})$ minimal medium. The culture was incubated at $25^{\circ} \mathrm{C}$ in $500 \mathrm{ml}$ Erlenmeyer flasks on a rotary shaker. Samples were taken at intervals and growth ( $\boldsymbol{A}$ ) was monitored by measuring $\mathrm{OD}_{600}$. Changes in the levels of metabolites in the culture medium were measured by HPLC: $\boldsymbol{\square}$, ferulic acid; 0 , vanillic acid.

(Krieg \& Holt, 1984) complemented with the data obtained from the API $20 \mathrm{NE}$ system. From these results, the identity of this isolate was confirmed as a strain of Pseudomonas fluorescens biovar V. This is an atypical Pseudomonas fluorescens since, when grown on ironfree media, the bacterium failed to produce fluorescent pigments. This strain has been deposited at NCIMB (Aberdeen, UK) under strain number NCIMB 40783.

\section{Growth of $P$. fluorescens AN103}

The ability of $P$. fluorescens AN103 to utilize different carbon substrates for growth was examined in liquid media. The results (Table 1 ) indicated that a number of 
(a)

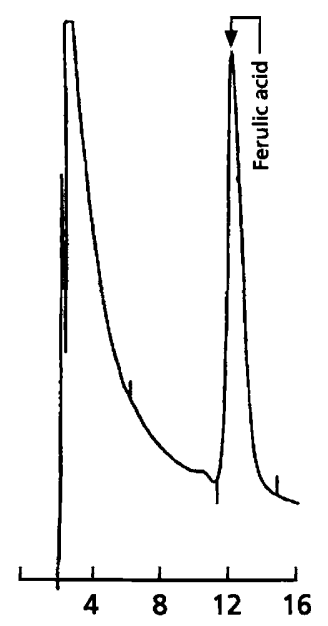

(b)

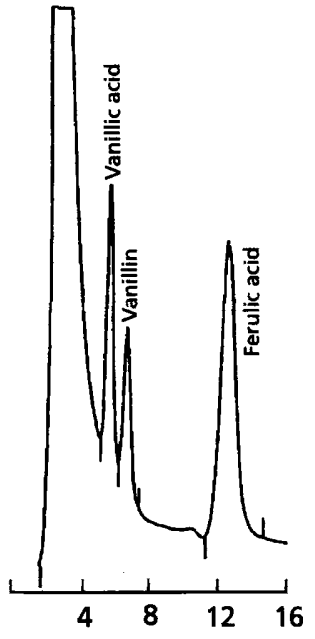

Retention time ( $\mathrm{min})$

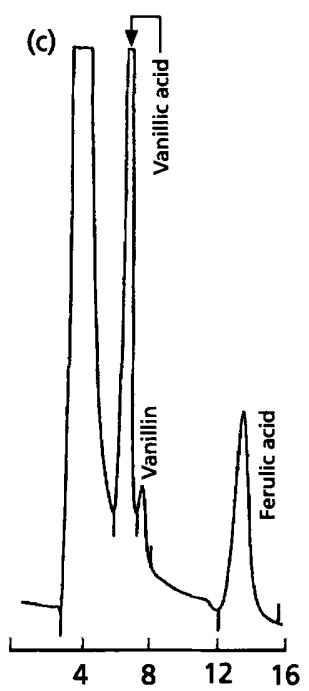

Fig. 2. Reverse-phase HPLC chromatograms showing the in vitro biotransformation of ferulic acid by cell-free extracts of ferulicacid-grown $P$. fluorescens AN103. Cell extracts were incubated at $25^{\circ} \mathrm{C}$ in $260 \mathrm{mM}$ phosphate buffer with ferulic acid and appropriate cofactors. Sample mixes were (a) $\mathrm{COASH}, \mathrm{ATP}$ and $\mathrm{MgCl}_{2}$, no cell extract, (b) COASH, ATP and $\mathrm{MgCl}_{2}$, cell extract, (c) COASH, ATP and $\mathrm{MgCl}_{2}, \mathrm{NAD}$ and cell extract. After $4 \mathrm{~h}$ incubation, $10 \mu \mathrm{l}$ samples were used for HPLC analysis. The eluted compounds were detected at $260 \mathrm{~nm}$ and their retention times were compared with those of authentic compounds. Identity was further confirmed by analysis of their UV spectra. In this column system, the retention times were: vanillic acid, $6.50 \mathrm{~min}$; vanillin, $7.61 \mathrm{~min}$; ferulic acid, $13.73 \mathrm{~min}$.
$\mathrm{C}_{6}-\mathrm{C}_{3}$ and $\mathrm{C}_{6}-\mathrm{C}_{1}$ phenolic compounds were utilized for growth, although glucose was the best growth substrate. Coumaric and caffeic acid but not cinnamic acid supported bacterial growth. Vanillin and protocatechuic aldehyde at $10 \mathrm{mM}$ could not support bacterial growth in liquid media. However, at $2 \mathrm{mM}$ vanillin was utilized as a sole source of carbon and energy. Whether a lower concentration of protocatechuic aldehyde could be metabolized was not examined. Vanillic acid was a better substrate than all the other phenolics examined, suggesting that some of these growth substrates may be exerting a toxic effect at $10 \mathrm{mM}$ concentration.

\section{Oxidation of metabolites by intact cells}

Washed cell suspensions of $P$. fluorescens AN103 grown on ferulic acid readily oxidized, without lag, a number of postulated intermediates as well as ferulic acid itself.

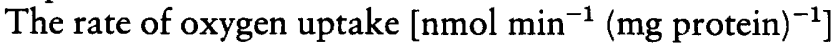
in the presence of various compounds as measured using the Warburg apparatus were as follows: ferulic acid, 832 ; vanillin, 184 ; vanillic acid, 610 ; and protocatechuic acid, 1008. The values shown were corrected for the endogenous oxygen uptake. The low total oxygen uptake in the presence of vanillin may reflect the toxicity of this compound.

\section{Analysis of ferulic acid transformation in culture media}

P. fluorescens AN103 rapidly utilized ferulic acid and the growth cycle was completed within $24 \mathrm{~h}$ (Fig. 1). Accumulation of vanillic acid was observed during the mid-exponential phase of growth and this product was itself subsequently utilized. The maximum level of vanillic acid was observed at $16 \mathrm{~h}$, at which time the yield of vanillic acid in the medium was $0.55 \mathrm{~g} \mathrm{l}^{-1}$. The identity of the products was confirmed by HPLC, TLC and UV spectral characteristics as well as MS analysis. In samples taken after $18 \mathrm{~h}$ growth, trace amounts of protocatechuic acid were observed. To establish whether low levels of other metabolites were present, phenolics were concentrated by ethyl acetate extraction of $200 \mathrm{ml}$ culture supernatant and analysed by HPLC. Only vanillic acid and protocatechuic acid were detected.

\section{Biotransformation of ferulic acid by cell-free extracts and cofactor requirements}

The ability of crude extracts prepared from $P$. fluorescens AN103 cells grown on ferulic acid to convert ferulic acid to vanillin and vanillic acid was investigated. In the presence of $\mathrm{CoASH}, \mathrm{MgCl}_{2}$ and ATP, $32 \%$ of added ferulic acid $(1 \mu \mathrm{mol})$ was converted to vanillin $(18 \%)$ and vanillic acid (14\%) within $4 \mathrm{~h}$ (Fig. 2 ). If the extracts were incubated for longer, more of the vanillin was converted to vanillic acid (data not shown). If the above components were supplemented with NAD, the amount of ferulic acid converted more than doubled to $68 \%$ (Fig. 2c). The major cleavage product was now vanillic acid, with only trace amounts of vanillin detectable. Cleavage of ferulic acid was not detected in the absence of CoASH or ATP, indicating that the in vitro cleavage of ferulic acid has an absolute requirement for these two cofactors. In the absence of added $\mathrm{MgCl}_{2}$, the rate of cleavage was reduced and only $10 \%$ $(0.1 \mu \mathrm{mol})$ of the added ferulic acid was converted.

\section{Biotransformation of vanillin by cell-free extracts}

Crude cell extracts of ferulic-acid-grown cells readily oxidized vanillin to vanillic acid (Fig. 3). In the absence of any additional cofactors, the rate of conversion was low : after $4 \mathrm{~h}$ incubation, less than $25 \%$ of the added vanillin was oxidized. However, in the presence of $\mathrm{NAD}$, all the vanillin was converted to vanillic acid, indicating the activity of NAD-linked vanillin dehydrogenase (Fig. 3c). The slow rate in the absence of NAD may have been due either to low levels of NAD present 

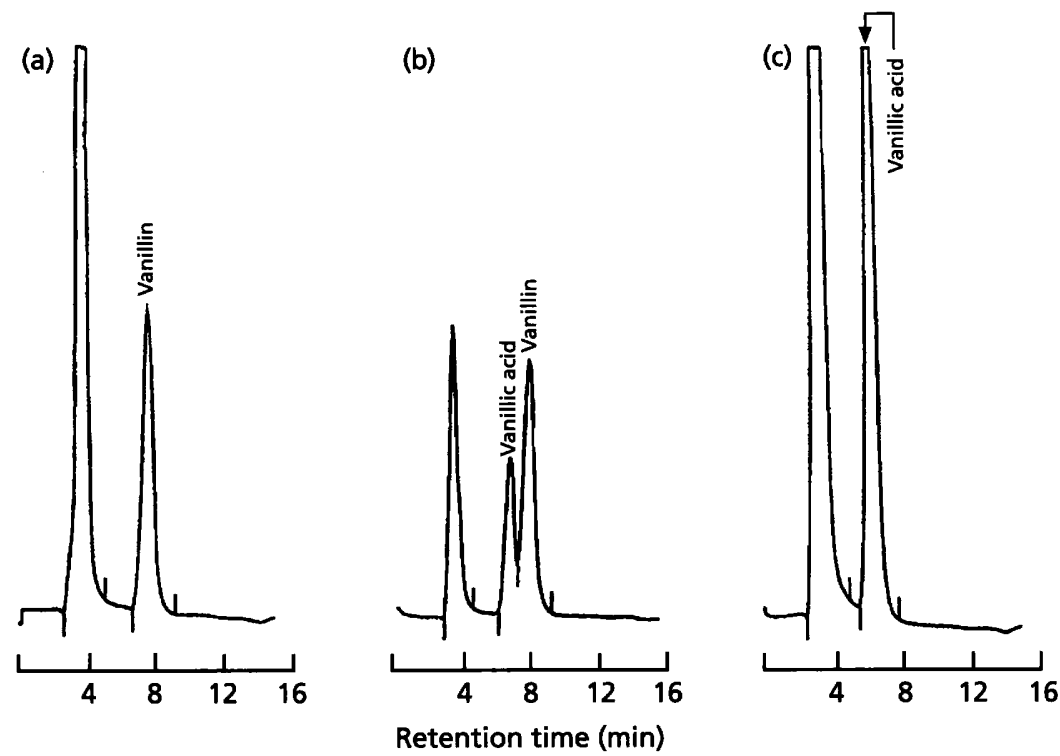

Fig. 3. Reverse-phase HPLC chromatograms showing the in vitro biotransformation of vanillin by cell-free extracts of ferulic acidgrown $P$. fluorescens AN103. Incubation conditions, HPLC analysis and retention times were as described for legend to Fig. 2 except that ferulic acid was not present in the sample mixes. Sample mixes contained (a) vanillin and NAD without cell extract, (b) vanillin with cell extract, (c) vanillin with NAD and cell extract.

in the crude extracts or to the presence of a non-specific aromatic aldehyde oxidase. Under identical experimental conditions, when vanillin was replaced with the same concentration of vanillic acid, reduction of the latter was not observed.

\section{Identification of the $C_{2}$ side-chain cleavage product}

Fig. 4 shows the ${ }^{13} \mathrm{C}$-NMR data obtained after transformation of some of the ferulic acid by cell-free extracts of ferulic-acid-grown cells. Detection of $\left[2-{ }^{13} \mathrm{C}\right]$ acetyl$\mathrm{CoA}$ (resonance at 29.92 p.p.m.) indicates that this is the product of the $\mathrm{C}_{2}$ side-chain cleavage during ferulic acid metabolism. The origin of the low-intensity signal at 62.5 p.p.m. was not identified; however, distortionlessenhancement-by-polarization-transfer analysis indicated that this signal was due to a carbon atom with a $\mathrm{CH}_{2}$ structural composition.

\section{Enzyme assays}

Crude cell-free extracts of $P$. fluorescens AN103 grown on ferulic acid displayed high levels of both ferulateCoA ligase and NAD-linked vanillin dehydrogenase (Table 2). No dehydrogenase activity could be detected when NAD was replaced with NADP. Neither activity was detected when the cells were grown on either vanillic or succinic acid minimal media. When cells were grown on vanillin, only the dehydrogenase was induced.

\section{DISCUSSION}

Because of increasing demand for natural food flavouring, there is considerable interest in utilizing ferulic acid and other phenolics as a cheap source of natural substrate for microbial fermentations aimed at the synthesis of vanillin and other flavour compounds (Hagedorn \& Kaphammer, 1994). A number of bacteria, yeast and fungi which degrade ferulic acid have been isolated (Ander \& Eriksson, 1978; Cartwright \& Smith, 1967; Gurujeyalakshmi \& Mahadevan, 1987; Huang et al., 1993; Omori et al., 1988; Sampaio \& van Uden, 1991; Sutherland et al., 1983). Based on manometric studies and the analysis of products in culture filtrate, vanillin, vanillic acid and protocatechuic acid have all been implicated as intermediates in the ferulic acid degradative pathway. However, the biochemical steps of the initial route of degradation have not been well characterized (Casey \& Dobb, 1992). In this paper we describe the isolation and characterization of a soil bacterium $P$. fluorescens biovar V strain AN103, which is capable of utilizing ferulic acid. The proposed pathway for ferulic acid metabolism in this organism is shown in Fig. 5.

In addition to ferulic acid, $P$. fluorescens AN103 utilized coumaric and caffeic acid as well as the possible metabolic intermediates vanillin, vanillic acid and protocatechuic acid. The fact that cinnamic acid did not support bacterial growth indicates that a hydroxy substitution at the para position is an essential structural requirement for the metabolism of these phenolics. Sinapinic acid, which has an additional methoxy substitution at the para position, was not metabolized. This inability of sinapinic acid or dimethoxy-substituted compounds to act as a growth substrate was also reported in other ferulate-degrading pseudomonads (Andredoni et al., 1984, 1995). Ferulate-grown cells were able to oxidize vanillin, vanillic acid and protocatechuic acid without lag, indicating that these metabolites are intermediates of the ferulic acid degradative pathway in P. fluorescens AN103. During growth on ferulic acid, transient accumulation of up to $0.55 \mathrm{~g}$ vanillic acid $\mathrm{l}^{-1}$ and trace amounts of protocatechuic acid were observed in the culture medium, providing further evidence for involvement of these phenolics as intermediates. However, no vanillin accumulated in the culture medium, 
(a)

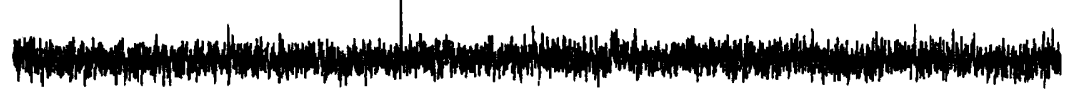

(b)

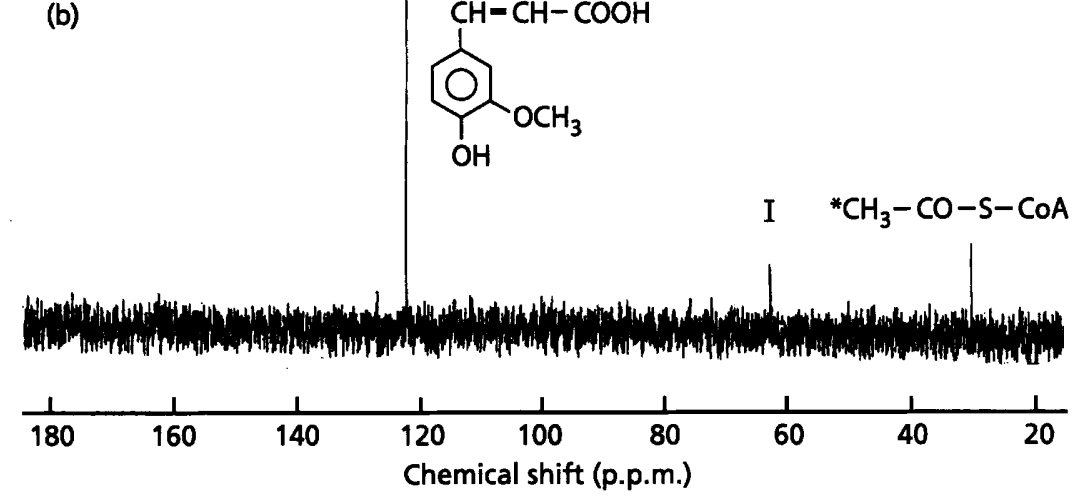

Fig. 4. ${ }^{13} \mathrm{C}-\mathrm{NMR}$ spectra to show the transformation of ferulic acid by cell-free extracts of ferulic-acid-grown $P$. fluorescens AN103. The samples were incubated for $8 \mathrm{~h}$ and contained $\left[2-{ }^{13} \mathrm{C}\right]$ ferulic acid, $\mathrm{COASH}$, $\mathrm{MgCl}_{2}$, ATP and NAD in the absence (a) or in the presence (b) of cell extract. I, unidentified possible intermediate.

Table 2. Activities of ferulate-CoA ligase and vanillin dehydrogenase in crude extracts of $P$. fluorescens AN103 grown on different carbon substrates.

The values shown are the mean of duplicate assays from three independent cultures.

\begin{tabular}{|lcc|}
\hline Growth substrate & \multicolumn{2}{c|}{ Enzyme activity $\left[\mathbf{n m o l ~} \mathbf{~ m i n}^{-1}(\mathbf{m g} \text { protein })^{-1}\right]$} \\
\cline { 2 - 3 } & Ferulate-CoA ligase & Vanillin dehydrogenase \\
\hline Ferulic acid & 5800 & 630 \\
Vanillin & 0 & 460 \\
Vanillic acid & 0 & 0 \\
Succinic acid & 0 & 0 \\
\hline
\end{tabular}

indicating that $P$. fluorescens AN103 is highly efficient at oxidizing this metabolite, which was found to be toxic at $10 \mathrm{mM}$.

Results presented here demonstrate, for the first time, the formation of vanillin from ferulic acid in vitro. This transformation had an absolute requirement for $\mathrm{CoASH}$ and ATP. In P. fluorescens AN103, the first step in the metabolism of ferulic acid is its activation to form feruloyl-CoA, as further confirmed by the detection of high levels of inducible ferulate-CoA ligase in cell extracts. The feruloyl-CoA thioester subsequently undergoes a side-chain cleavage to form vanillin and a $\mathrm{C}_{2}$ cleavage product, which we identified as acetyl-CoA by ${ }^{13} \mathrm{C}-\mathrm{NMR}$. Addition of NAD enhanced the overall rate of conversion. This is the first example where acetyl-CoA has been experimentally shown to be the $\mathrm{C}_{2}$ cleavage product. The aromatic product of the sidechain cleavage of ferulic acid is vanillin, which is subsequently oxidized to vanillic acid via an inducible NAD-linked vanillin dehydrogenase. High levels of this enzyme were measured in both ferulic-acid- and vanillingrown cells. A similar role for this type of dehydrogenase in ferulate metabolism was implicated in Pseudomonas acidovorans (Toms \& Wood, 1970) although the initial transformation of ferulic acid to vanillin was achieved via a different (non-CoA-requiring) route to that observed in this study. In the absence of added NAD, crude extracts of ferulic-acid-grown cells showed variable but low levels of activity for converting vanillin to vanillic acid. Our results cannot identify whether this was due to limiting amounts of NAD in the crude extract or, alternatively, to the presence of an aromatic aldehyde oxidase, as has been reported in Streptomyces 


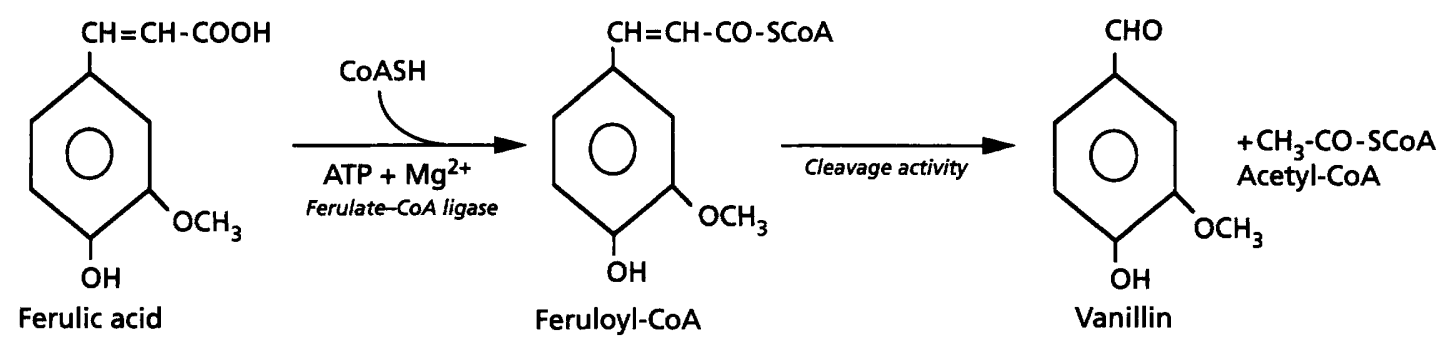

Ferulic acid

Feruloyl-CoA

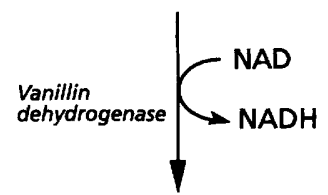

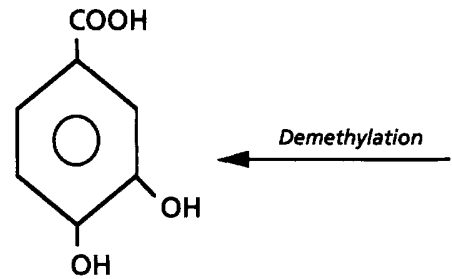

Protocatechuic acid

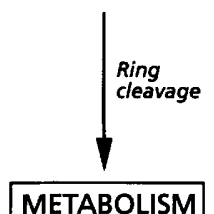

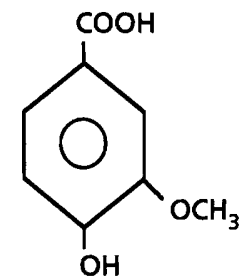

Vanillic acid

Fig. 5. Proposed pathway of ferulic acid metabolism in P. fluorescens AN103.

viridosporus (Crawford et al., 1982) and in Bacillus subtilis (Gurujeyalakshmi \& Mahadevan, 1987). Detection of low levels of protocatechuic acid in the culture medium indicates that in P. fluorescens AN103, further metabolism of vanillic acid occurs via demethoxylation (Brunel \& Davison, 1988; Cartwright \& Buswell, 1967; Cartwright \& Smith, 1967; Ribbons, 1970) followed by an ortho (Omori et al., 1988) or meta (Toms \& Wood, 1970) ring cleavage of protocatechuic acid.

The biochemical mechanism of $\mathrm{C}_{2}$ side-chain cleavage has not been established in this system. If, however, the unassigned $\mathrm{CH}_{2}$ resonance at 62.5 p.p.m. in our NMR studies is due to a metabolic intermediate, then speculatively this may be 4-hydroxy-3-methoxybenzoylacetyl$\mathrm{CoA}$, which would result from hydration and then the oxidation of feruloyl-CoA. Two different types of cleavage mechanism have been proposed in a variety of organisms: (a) $\beta$-oxidation of substituted cinnamic acids results in the formation of the corresponding benzoic acid derivatives (Iyayi \& Dart, 1982; Vollmer et al., 1965) and (b) non-oxidative cleavage of the side-chain produces the corresponding benzaldehyde derivatives, which can then be subsequently oxidized to the benzoic acid (French et al., 1976; Toms \& Wood, 1970; Yazaki et al., 1991). The mechanism of ferulate cleavage in $P$. fluorescens AN103 may not fit either category. $\beta$ Oxidation-type cleavage would produce vanillic acid, whereas all our experimental data suggest that vanillin was the immediate product. Non-oxidative-type cleavage mechanisms reported in the literature so far do not require the activation of feruloyl CoA as observed in this study. These findings suggest the possibility of a novel $\mathrm{C}_{2}$-cleavage mechanism in this organism.

The ferulic acid degradative pathway in P. fluorescens AN103 is tightly, but not co-ordinately, regulated; the structural genes for the enzymes of the pathway appear to be induced only in the presence of the enzyme substrate. A similar inducible system for ferulic acid degradation was reported in Bacillus subtilis (Gurujeyalakshmi \& Mahadevan, 1987).

The metabolism of ferulic acid by P. fluorescens AN103 can potentially be exploited to provide the valuable flavour compounds vanillin and vanillic acid. Assuming an analogous metabolic route for coumaric acid, which is also an abundant constituent of plant cell walls, the accumulation of the corresponding flavour compounds, $p$-hydroxybenzaldehyde and $p$-hydroxybenzoic acid, should also be possible. Furthermore, the proposed metabolic pathway includes an interesting enzymic 
mechanism for $\mathrm{C}_{2}$ cleavage and has initiated the detailed characterization of the specific genes and proteins involved, the results of which will be presented elsewhere.

\section{ACKNOWLEDGEMENTS}

We thank M. Parker for preparation of electron micrographs and M. J. E. Hewlins for NMR spectroscopy. We are grateful to A. Parr for assistance with HPLC analysis and T. Brocklehurst for assistance in bacterial identification. We would like to thank M. Rhodes and N. Walton for helpful discussions.

\section{REFERENCES}

Ander, P. \& Eriksson, K. E. (1978). Lignin degradation and utilisation by microorganisms. Prog Ind Microbiol 14, 1-58.

Andreoni, V., Galli, E. \& Galliani, G. (1984). Metabolism of ferulic acid by a facultatively anaerobic strain of Pseudomonas cepacia. Syst Appl Microbiol 5, 299-304.

Andreoni, V., Bernasconi, S. \& Bestetti, G. (1995). Biotransformation of ferulic acid and related compounds by mutant strains of Pseudomonas fluorescens. Appl Microbiol Biotechnol 42, 830-835.

Bradford, M. M. (1976). A rapid and sensitive method for the quantitation of microgram quantities of protein utilizing the principle of protein-dye binding. Anal Biochem 72, 248-254.

Brunel, F. \& Davison, J. (1988). Cloning and sequencing of Pseudomonas gene encoding vanillate demethylase. J Bacteriol 170, 4924-4930.

Cartwright, N. J. \& Buswell, J.A. (1967). The separation of vanillate $O$-demethylase from protocatechuate 3,4 -oxygenase by ultracentrifugation. Biochem J 105, 767-770.

Cartwright, N. J. \& Smith, A. R. W. (1967). Bacterial attack on phenolic ethers. An enzyme system demethylating vanillic acid. Biochem J 102, 826-840.

Casey, J. \& Dobb, R. (1992). Microbial routes to aromatic aldehydes. Enzyme Microb Technol 14, 739-747.

Clausen, M., Lamb, C. J., Megnet, R. \& Doerner, P. W. (1994). PAD1 encodes phenylacrylic acid decarboxylase which confers resistance to cinnamic acid in Saccharomyces cerevisiae. Gene $142,107-112$.

Crawford, D. L. \& Crawford, R. L. (1980). Microbial degradation of lignin. Enzyme Microb Technol 2, 11-22.

Crawford, D. L., Sutherland, J. B. \& Pometto, A. L. (1982). Production of an aromatic aldehyde oxidase by Streptomyces viridosporus. Arch Microbiol 131, 351-355.

Edlin, D. A. N., Narbad, A., Dickinson, J. R. \& Lloyd, D. (1995). The biotransformation of simple phenolic compounds by Brettanomyces anomalus. FEMS Microbiol Lett 125, 311-316.

French, C. J., Vance, C. P. \& Towers, G. H. N. (1976). Conversion of $p$-coumaric acid to $p$-hydroxybenzoic acid by cell free extract of Polyporus hispidus. Phytochemistry 15, 564-566.

Gurujeyalakshmi, G. \& Mahadevan, A. (1987). Dissimilation of ferulic acid by Bacillus subtilis. Curr Microbiol 16, 69-73.

Hagedorn, S. \& Kaphammer, B. (1994). Microbial biocatalysis in the generation of flavor and fragrance chemicals. Annu Rev Microbiol 48, 773-800.

Henderson, M. E. K. (1961). Isolation, identification and growth of some soil hyphomycetes and yeast-like fungi which utilise aromatic compounds related to lignin. J Gen Microbiol 26, 149-154.

Huang, Z., Dostal, L. \& Rosazza, J. P. N. (1993). Microbial transformations of ferulic acid by Saccharomyces cerevisiae and Pseudomonas fluorescens. Appl Environ Microbiol 59, 2244-2250.

Huang, Z., Dostal, L. \& Rosazza, J. P. N. (1994). Purification and characterization of a ferulic acid decarboxylase from Pseudomonas fluorescens. J Bacteriol 176, 5912-5918.

Ishikawa, H., Schubert, W. J. \& Nord, F. F. (1963). Investigations on lignin and lignification. XXVIII. The degradation by Polyporus versicolor and Fomes fomentarius of aromatic compounds structurally related to softwood lignin by white rot fungi. Arch Biochem Biophys 100, 131-139.

lyayi, C. B. \& Dart, R. K. (1982). The degradation of p-coumaryl alcohol by Aspergillus flavus. J Gen Microbiol 128, 1473-1482.

Krieg, N. R. \& Holt, J. G. (1984). Bergey's Manual of Systematic Bacteriology, vol. 1. Baltimore: Williams \& Wilkins.

Labuda, I. M., Keon, K. A. \& Goers, S. K. (1993). Microbial bioconversion process for the production of vanillin. In Progress in Flavour Precursor Studies, pp. 477-482. Edited by P. Schreier \& P. Winterhalter. Carol Stream, IL: Allured Publishing Corporation.

Narbad, A., Hewlins, M. J. E. \& Callely, A. G. (1989). ${ }^{13}$ C-NMR studies of acetate and methanol metabolism by methylotrophic Pseudomonas strains. J Gen Microbiol 135, 1469-1477.

Nazareth, S. \& Mavinkurve, S. (1986). Degradation of ferulic acid via 4-vinyl guaiacol by Fusarium solani (Mart). Can J Microbiol 32, 494-497.

Omori, T., Hatakeyama, K. \& Kodama, T. (1988). Protocatechuic acid production from trans-ferulic acid by Pseudomonas sp. HF1 mutants defective in protocatechuic acid catabolism. Appl Microbiol Biotechnol 29, 497-500.

Ötuk, G. (1985). Degradation of ferulic acid by Escherichia coli. $J$ Ferment Technol 63, 501-506.

Pearl, J. A. \& Beyer, D. L. (1951). Reactions of vanillin and its derivative compounds. XI. Cinnamic acids derived from vanillin and its related compounds. J Org Chem 16, 216-220.

Provan, G. J., Scobbie, L. \& Chesson, A. (1994). Determination of phenolic acids in plant cell walls by microwave digestion. $J$ Sci Food Agric 64, 63-65.

Rahouti, M., Siegle-Murandi, F., Steiman, R. \& Eriksson, K. E. (1989). Metabolism of ferulic acid by Paecilomyces variotti and Pestalotia palmarum. Appl Environ Microbiol 55, 2391-2398.

Ribbons, D. W. (1970). Stoichiometry of O-demethylase activity in Pseudomonas aeruginosa. FEBS Lett 8, 101-104.

Rhodes, M. J. C. \& Wooltorton, L. S. C. (1973). Formation of CoA esters of cinnamic acid derivatives by extracts of Brassica napobrassica root tissue. Phytochemistry 12, 2381-2387.

Rosazza, J. P. N., Huang, Z., Dostal, L., Volm, T. \& Rousseau, B. (1995). Review: biocatalytic transformations of ferulic acid: an abundant aromatic natural product. J Ind Microbiol 15, 457-471.

Sampaio, J. P. \& van Uden, N. (1991). Rhodotorula ferulica sp., a yeast that degrades ferulic acid and other phenolic compounds. Syst Appl Microbiol 14, 146-149.

Sutherland, J. B., Crawford, D. L. \& Pometto, A. L. (1983). Metabolism of cinnamic, $p$-coumaric and ferulic acids by Streptomyces setonii. Can J Microbiol 29, 1253-1257.

Toms, A. \& Wood, J. M. (1970). The degradation of trans-ferulic acid by Pseudomonas acidovorans. Biochemistry 9, 337-343.

Vollmer, K. O., Reisener, H. J. \& Grisebach, H. (1965). The 
formation of acetic acid from $p$-hydroxycinnamic acid during its degradation to $p$-hydroxybenzoic acid in wheat shoot. Biochem Biophys Res Commun 21, 221-225.

Yazaki, K., Heide, L. \& Tabata, M. (1991). Formation of $p$ hydroxybenzoic acid from $p$-coumaric acid by cell free extract of Lithospermum erythrorbizon cell culture. Phytochemistry 30, 2233-2236.
Zenk, M. H., Ulbrich, B., Brusse, J. \& Stockigt, J. (1980). Procedure for enzymatic synthesis and isolation of cinnamoyl-CoA thiolesters using bacterial system. Anal Biochem 101, 182-187.

Received 12 November 1997; revised 2 January 1998; accepted 4 February 1998. 